\title{
Zooplankton in two small reservoirs of the Tuva Republic
}

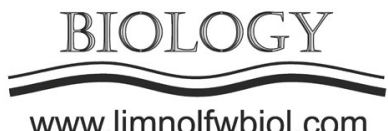

Kirova N.A.*

Tuvinian Institute for Exploration of Natural Resources of SB RAS, Tuva Republic, Kyzyl, Internacyonalnaya str., 117A, 667007, Russia

\begin{abstract}
The article provides information on the species composition and quantitative indicators of zooplankton in two small mountain reservoirs of the Tuva Republic: the Eerbek and Turan. They reflect the first and the third years of the ecosystem existence after seasonal drawdown. Regulation shows a typical pattern in the distribution of zooplankton in the reservoirs: an increase in density in the dam section. In general, the reservoir zooplankton has a floodplain type of formation. The existence periods of reservoirs influences the zooplankton structure and its development: regulation in the first year determines the development of crustacean zooplankton (represented mainly by cladocerans), usually with monodominance; over three years, all main groups of zooplankton develop, but drawdowns interrupt the formation on the normal ecosystem in the reservoir.
\end{abstract}

Keywords: small reservoirs, zooplankton, Tuva, regulation

\section{Introduction}

In the Tuva Republic, apart from the wellknown large Sayano-Shushenskaya Dam, several small artificial water bodies were created in the 1980s. They were intended for irrigation of fields, watering places and regulation of river flow. Following the aims and tasks, two small reservoirs were also created, whose direct purpose is lost now, and they are mainly popular among the fishing amateurs. Nevertheless, they retain their functioning, being seasonal drawdown reservoirs, which influences the existence features of zooplankton in them. Special scientific research supplemented the construction of such large objects as the SayanoShushenskaya Dam, whereas the literature concerning zooplankton in small reservoirs are rather scarce (Kirova, 2014). Our study aims to determine differences in the species composition and quantitative characteristics of the zooplankton in the Eerbek and Turan reservoirs, regarding their different existence periods.

\section{Material and methods}

The Eerbek and Turan reservoirs were created on the mountain rivers with the same names, the Eerbek (the right tributary of the Ulug-Khem River (the Upper Yenisei)) and the Turan (the left tributary of the Uyuk River, the Biy-Khem basin (Big Yenisei)). The Eerbek reservoir occupies the middle flow of the Eerbek River, in $15 \mathrm{~km}$ from its estuary; the Turan reservoir is closer to the upper flow of the Turan River, in $25 \mathrm{~km}$ from the estuary (Fig. 1).

According to the classification of Avakyan (Avakyan et al., 1987). both reservoirs are small. They are shallow and river valley reservoirs in origin. The water management passport (Water management..., 1983; 1985) states that both reservoirs have seasonal regulation, but de facto the water drawdown does not occur annually. Based on the data of Tuva Institute for Exploration of Natural Resources of the Siberian Branch of the RAS (TuvIENR SB RAS), waters in both reservoirs are fresh (Table 1); in the Eerbek reservoir, the water is calcium-sodium bicarbonate, soft (1.95 meq/l); in the Turan reservoir - calcium-magnesium bicarbonate, also soft $(1.55 \mathrm{meq} / \mathrm{l})$. The coastal zones of the reservoirs warm up well; water temperature in summer reaches $20-23^{\circ} \mathrm{C}$.

Zooplankton was sampled and collected by standard methods (Rukovodstvo..., 1992) at the beginning of August 2017. Samples were collected in the centre of upper, middle and dam sections. At the stations with depths of $\leq 1 \mathrm{~m}$, samples were taken by 100-1 pouring through a planktonic net with a $100 \mu \mathrm{m}$-cell size. At other sites, samples were taken totally from the bottom to the surface with the Juday net. A 4\% formalin solution was used for fixation. The determination was carried out as possible to the species, Harpacticoida was not identified (Opredelitel'..., 1995). Simultaneously, the water temperature was measured, and the water was sampled for analysis of water chemistry. 
Table 1. Physical and geographical parameters of the investigated reservoirs

\begin{tabular}{|c|c|c|c|c|c|c|c|}
\hline Name & Coordinates & Height, $\mathrm{m}$ asl & Area, $\mathrm{km}^{2}$ & Depths max, (av), m & $\mathrm{T}^{\circ} \mathrm{C}$ & TDS, g/1 & $\mathrm{pH}$ \\
\hline Eerbek & $\begin{array}{l}51.726897 \\
94.317023\end{array}$ & 680 & 0.51 & $6(4)$ & $15-20$ & $0.4^{*}$ & $8.01 *$ \\
\hline Turan & $\begin{array}{l}52.246635 \\
93.908136\end{array}$ & 934 & 1.95 & $8(5)$ & $14-23$ & $0.125^{*}$ & $7.22 *$ \\
\hline
\end{tabular}

Note: * TuvIENR SB RAS data

\section{Results}

The zooplankton from the two reservoirs contains 27 species from 20 genera, 10 families and 2 subfamilies as well as 7 orders of animals. Most taxa (88\%) are crustaceans. Among them, the bulk of taxa belongs to cladocerans, 17 species $(68 \%$ of the total number) and copepods, 5 species (20\%); there are also 3 species of rotifers (12\%). Families Chydoridae and Daphniidae reach the highest species diversity, eight species each (Table 2). Zoogeographically (according to Rivier et al., 2001), most taxa are cosmopolitan (47\%); the share of palearctic ones is $38 \%$ and holarctic $15 \%$, i.e. fauna is represented by widespread species. In terms of biotopes, eurytopic forms (50\%) as well as littoral (11\%), phytophilic (19\%), planktonic (8\%), and benthic (4\%) species represent the community.

The Eerbek reservoir. In the composition of the Eerbek reservoir, we have found 13 species, of which 9 are Cladocerans, 3 - Copepods and 1 representative of Rotifers (Table 2). The density of zooplankton is unevenly distributed along the water area; the minimum values ( 7.2 thou specimens $/ \mathrm{m}^{3}$ ) are in the upper section of the reservoir; in the middle section, the total number increases 8 times and biomass - 15.4 times; in the dam section, the number increases 10.3 times and the biomass - almost 19 times (Fig. 2). Throughout the water area of the reservoir, the species composition is conformed: D. longispina, D. pulex, $B$. longirostris, and $A$. denticornis. In the coastal zone, there are all species of aquatic vegetation from the general list, although in a single number.

In the upper section, Cladocerans $D$. longispina (52\%) and $B$. longirostris (31\%), as well as Copepod $A$. denticornis (13\%), compose the structure-forming core; in the middle and dam sections, $D$. longispina prevails (79-98\%). Planktonic and eurytopic species are the

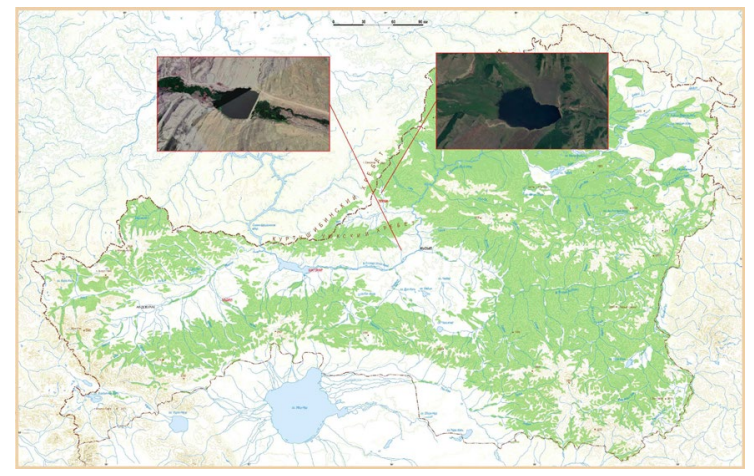

Fig.1. Schematic location map of the Eerbek (below) and Turan (above) reservoirs on the territory of the Tuva Republic

main in the number. The value of species diversity index in the upper section (0.94) decrease in the middle and dam sections ( 0.46 and 0.52 ), which is due to the dominance of the species $D$. longispina.

Turan reservoir. There are 16 species in the zooplankton composition, of which 11 are Cladocerans, 4 - Copepods and 3 - Rotifers (Table 2). The number of the species found in the upper section is 13 , in the middle and dam sentions - 14 and 8, respectively. Throughout the water area, the composition of the dominant organisms is the same, and it includes nauplii of Copepoda (27-48\%), C. pulchella (20-59\%), H. mira (10-16\%), B. longirostris (6-7\%), M. viridis (8-13\%), D. brachiurum (5-6\%), and D. galeata (6\%), i.e. mainly eurytopic and littoral species. The number and biomass increase from the upper section towards the dam (Fig. 3). Low biomass indices against high abundance indices are due to prevailing nauplii of Copepoda (up to 59\%) and "lightweight"ceriodaphnia and rotifers. a

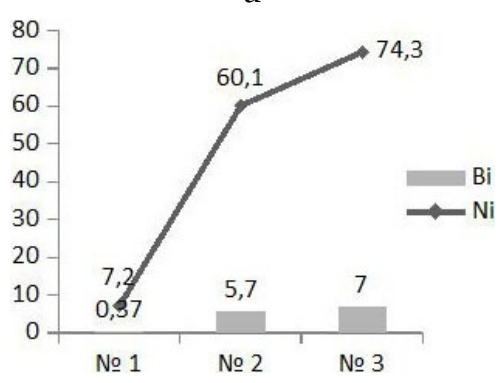

b

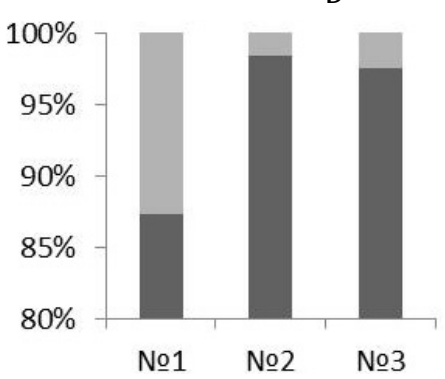

C

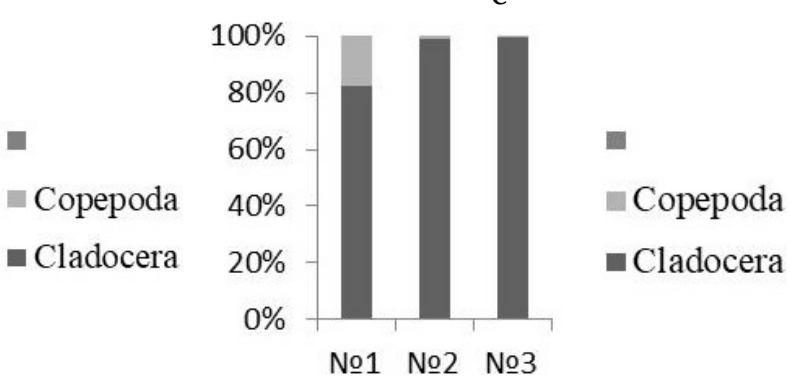

Fig.2. The number (N) (thou specimens $/ \mathrm{m}^{3}$ ) and biomass (B) $\left(\mathrm{g} / \mathrm{m}^{3}\right)$ (a) as well as the share of taxonomic groups by the total number (b) and biomass (c) of zooplankters from the Eerbek reservoir. Sampling stations Nos. 1-3 
Table 2. Taxonomic composition of zooplankton from the Eerbek and Turan reservoirs

\begin{tabular}{|c|c|c|c|c|}
\hline Taxon & Zoogeography & Biotope & Eerbek & Turan \\
\hline $\begin{array}{l}\text { Type Rotifera } \\
\text { Class Archiorotatoria, Markevich,1990 } \\
\text { Order Bdelloida Hudson,1884 } \\
\end{array}$ & - & - & + & + \\
\hline $\begin{array}{l}\text { Class Eurotatoria Markevich, } 1990 \\
\text { Order Transversiramida Markevich, } 1990 \\
\text { Family Brachionidae Ehrenberg, } 1838 \\
\text { Brachionus sp }\end{array}$ & - & - & + & - \\
\hline Kerathella quadrata (Müller, 1786) & $\mathrm{C}$ & Eut & + & - \\
\hline $\begin{array}{l}\text { Famiy Mitilinidae } \\
\text { Mitilina mucronata (Muller,1773) }\end{array}$ & $\mathrm{H}$ & $\mathrm{Ph}$ & - & + \\
\hline $\begin{array}{l}\text { Order Protoramida Markewich, } 1990 \\
\text { Family Hexarthridae Bartos, } 1958 \\
\text { Hexarthra mira (Hudson, 1871) } \\
\end{array}$ & $\mathrm{C}$ & $\mathrm{L}$ & - & + \\
\hline $\begin{array}{l}\text { Order Saltiramida } \\
\text { Family Asplanchniidae } \\
\text { Asplanchna priodonta Gosse, } 1850 \\
\end{array}$ & C & Eut & - & + \\
\hline $\begin{array}{l}\text { Order Ctenopoda } \\
\text { Family Sididae Baird, } 1850 \\
\text { Diaphanosoma brachyurum (Liévin, 1848) } \\
\end{array}$ & $P$ & Eut & - & + \\
\hline $\begin{array}{l}\text { Order Anomopoda Sars, } 1865 \\
\text { Family Bosminiidae Baird,1845 } \\
\text { Bosmina longirostris (O.F. Müller, 1785) } \\
\end{array}$ & $\mathrm{C}$ & Eut & + & + \\
\hline $\begin{array}{l}\text { Family Daphniidae Straus, } 1820 \\
\text { Daphnia galeata Sars, 1864* }\end{array}$ & $\mathrm{P}$ & $\mathrm{Pl}$ & - & + \\
\hline D. longispina (O.F. Müller, 1785) & $\mathrm{P}$ & $\mathrm{Pl}$ & + & - \\
\hline D. pulex Leydig, 1860 & $\mathrm{H}$ & Eut & + & \\
\hline Simocephalus vetulus (O.F. Müller, 1776) & $\mathrm{P}$ & $\mathrm{L}, \mathrm{Ph}$ & - & + \\
\hline Scapholeberis mucronata (O.F. Müller, 1776) & $\mathrm{P}$ & $\mathrm{Bt}, \mathrm{Ph}$ & - & + \\
\hline Ceriodaphnia dubia Richard, 1894* & $\mathrm{C}$ & $\mathrm{Pl}, \mathrm{L}$ & + & - \\
\hline C. pulchella Sars, 1862 & $\mathrm{P}$ & Eut & - & + \\
\hline C.quadrangula (O.F. Müller, 1785) & $\mathrm{P}$ & Eut & - & + \\
\hline $\begin{array}{l}\text { Family Chydoridae Dybowski et Grachowski, } 1894 \\
\text { Grapholeberis testudinaria (Fisher, 1851) }\end{array}$ & $\mathrm{C}$ & $\mathrm{L}$ & - & + \\
\hline Coronatella rectangula (Sars, 1862) & $\mathrm{P}$ & Eut & + & - \\
\hline Alona costata Sars, 1862 & $\mathrm{C}$ & $\mathrm{L}, \mathrm{Ph}$ & - & + \\
\hline Alona quadrangularis (Müller, 1785) & $\mathrm{C}$ & $\mathrm{Ph}, \mathrm{L}$ & + & - \\
\hline Alona guttata Sars, 1862 & $\mathrm{C}$ & $\mathrm{L}$ & + & - \\
\hline Alona affinis (Leydig, 1860) & $\mathrm{C}$ & $\mathrm{Ph}$ & + & - \\
\hline Chydorus sphaericus (O.F. Müller, 1785) & $\mathrm{C}$ & Eut & + & + \\
\hline Pleuroxus truncatus (O.F. Müller,1785) & $\mathrm{H}$ & $\mathrm{L}, \mathrm{Ph}$ & - & + \\
\hline $\begin{array}{l}\text { Family Cyclopinae Burmeister, } 1834 \\
\text { Megacyclops viridis (Jurine, 1820) }\end{array}$ & $\mathrm{C}$ & Eut & + & + \\
\hline Mesocyclops leuckarti (Claus,1857) & $\mathrm{P}$ & Eut & - & + \\
\hline Cyclops vicinus Ulyanin, 1875 & $\mathrm{P}$ & Eut & - & + \\
\hline Cyclops sp. & - & - & + & - \\
\hline $\begin{array}{l}\text { Class Maxillopoda Edwards, } 1840 \\
\text { Subclass Copepoda Edwards, } 1840 \\
\text { Order Cyclopoida Burmeister, } 1834 \\
\text { Subfamily Eucylopinae Kiefer, } 1927 \\
\text { Eucyclops serrulatus (Fischer, 1851) }\end{array}$ & $\mathrm{C}$ & Eut & + & - \\
\hline $\begin{array}{l}\text { Order Calanoida Sars, } 1903 \\
\text { Family Diaptomidae Baird, } 1850 \\
\text { Acanthodiaptomus denticornis Wierzejski, } 1887\end{array}$ & $\mathrm{H}$ & $\mathrm{L}$ & + & + \\
\hline Diaptomus sp & - & - & - & + \\
\hline Harpacrocoida gen. sp. & - & - & + & + \\
\hline
\end{tabular}

Note: P - palearctic, H - holarctic, C - cosmopolitan (Opredelitel'..., 1995); Eut - eurytopic, Ph - phytophilic, L- littoral, $\mathrm{Bt}$ - benthic, Pl- planktonic (Rivier et al., 2001). 


\section{Discussion}

Discussing the reasons for the revealed differences, it is worth noting a high reproductive potential of the members of the genera Bosmina, Ceriodaphnia and Daphnia, which is almost four times higher than that of copepods (Popkov and Golubykh, 2005). Perhaps this is the reason for the dominance of the members of these genera. The Eerbek reservoir, where the coastal zone is the most warmed up (up to $23^{\circ} \mathrm{C}$ ), having aquatic vegetation, shows the bulk of phytophilic species: $S$. mucronata, $P$. trigonellus, A. costata, G. testudinaria, and $P$. truncatus. Changes in the species diversity indices are as follows: in the dam section its minimum value (1.6) is accompanied by the dominance of $C$. pulchella (39\%) and D. brachiurum (5\%); in the upper and middle sections of the reservoir, the value is 2.24 and 1.89, respectively. The dominating core of each section included three-four species. In all sections, the share of the Copepoda nauplii is also significant.

An urgent issue is the quality of water in the reservoirs. Zooplankton contains 22 species that indicate the water saprobity. Among them, the quality indicators of 0 and $0-\beta$ are $77 \%$. The values of the indicators in the Eerbek reservoir (1.7-1.98) correspond to moderately polluted waters. The water from the upper section of the Turan reservoir is characterized as pure (1.4); in the middle and dam sections - moderately polluted (1.59 and 1.51) (Makrushin, 1974; Sladecek, 1983). Since reservoirs are located at a distance from settlements and do not experience anthropogenic impact, the natural processes, which occur during the flooding of the surrounding areas, influence water quality.

There are four common species in the two reservoirs: B. longirostris, $C$. sphaericus, $M$. viridis, and $A$. denticornis. The Sorensen-Chekanovsky similarity index is 0.27 , i.e. species composition is very specific for each reservoir. It is largely determined by the plankton fauna from the upstream water bodies, and the mountain rivers Eerbek and Turan play a transit role. High current velocities $(0.5-0.7 \mathrm{~m} / \mathrm{s})$ and straight channels do not allow the development of zooplanktonic species, which are typical of stagnant water bodies.

Among three types of zooplankton formation in reservoirs (lake, floodplain and river) (Luferova, 1964), the floodplain type is typical of the Eerbek and Turan reservoirs. In the upstream floodplain water bodies of the Eerbek River, we have found A. denticornis, $C$. spahericus, A. affinis, C. rectangula, E. serrulatus, M. viridis, $D$. pulex, and $D$. longispina. In the upstream channel of the Eerbek River, there are single specimens of C. rectangula, C. Sphaericus and E. serrulatus, the members of the orders Harpacticoida and Bdelloida. In the channel of the Turan River, we have found $S$. vetulus, $M$. viridis, C. quadrangula, B. longirostris, and D. Longispina, immature stages of Cyclopes. There is a similar composition of the plankton fauna in several upstream water bodies.

The processes that take place during the development and formation of biota in reservoirs are long-term and take years. There are three stages in the development of reservoirs: formation, depression and relative stabilization (Sharonov, 1966; Kudersky, 1992; Krylov, 2014). Biota of the investigated reservoirs is at the first stage, including a change in the composition and the quantitative development of limnophilic components as well as a change in the proportion of certain groups, but the seasonal drawdown interrupts this process. The 2017 study at the Eerbek reservoir was conducted after the water drawdown in autumn 2016. In fact, we observed the state of zooplankton in the first year after the regulation. In this case, an increased role of crustacean zooplankton is a natural phenomenon (Vorobyova et al., 1981; Dzyuban and Dzyuban, 1976). Based on the 2012 data, which were obtained in the second year of the reservoir existence (there was no drawdown in the preceding year), we revealed that against the mass development of cladocerans (up to $90 \%$ ) and dominance of $B$. longirostris, $D$. longispina and C. shaericus, the share of copepods and rotifers, despite the small number, was 5\% each (Kirova, 2014). At the time of our investigations, the Turan reservoir had no drawdown during two preceding years; therefore, in 2017, we observed the third year of its existence. We indicate that the different existence periods without drawdowns explain the superiority of the Turan reservoir over the Eerbek reservoir in the number of species and dominants as well as the development of rotifers and copepods.

\section{Conclusion}

The duration of the reservoir existence infuences the structure of the zooplankton community: regulation in the first year determines the development of the crustacean zooplankton with prevailing cladocerans a

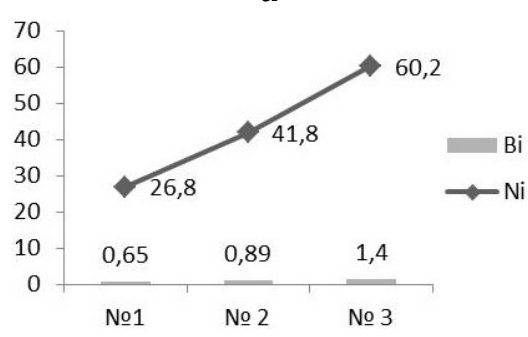

b

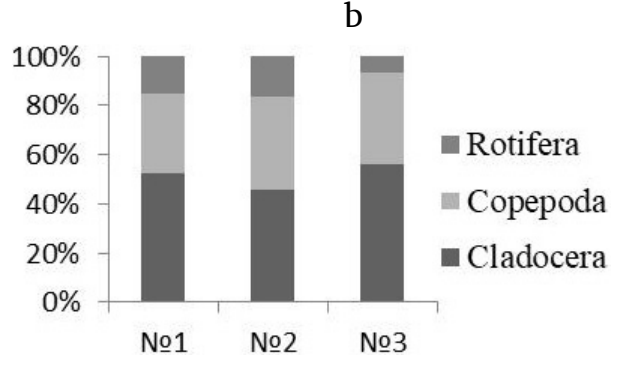

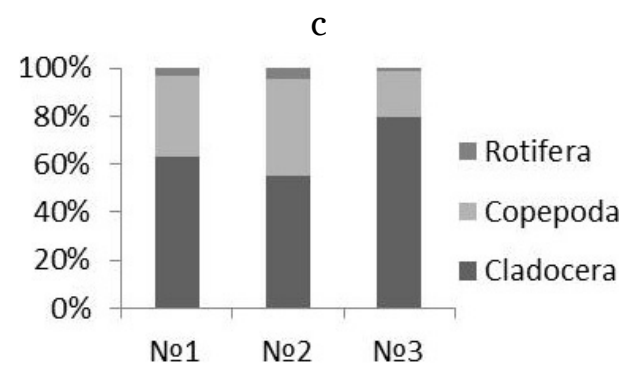

Fig.3. Number (N) (thou specimens $/ \mathrm{m}^{3}$ ) and biomass (B) $\left(\mathrm{g} / \mathrm{m}^{3}\right)$ (a) as well as the share of taxonomic groups by the total number (b) and biomass (c) of zooplankters from the Turan reservoir. Sampling stations Nos. 1-3 
and dominance of one species throughout the water area; over three years of the existence, the species diversity of plankton increases; the members of other groups, rotifers and copepods, develop. At the same time, the reservoir drawdown returns its community to the initial stage as in the first year of regulation.

\section{References}

Avakyan A.B., Saltankin V.P., Sharapov V.A. 1987. Vodokhranilishcha. Moscow: Mysl. (in Russian)

Dzyuban N.A., Dzyuban M.N. 1976. Biologicheskiye produktsionnyye protsessy $\mathrm{v}$ basseyne Volgi. Leningrad: Nauka. (in Russian)

Kirova N.A. 2014. The first information about the zooplankton of the Eerbek reservoir (Central Tuva). Sostoyaniye i Osvoyeniye Prirodnykh Resursov Tuvy i Sopredel'nykh Regionov Tsentral'noy Azii. EkologoEkonomicheskiye Problemy Prirodopol'zovaniya [State and Development of Natural Resources of Tuva and the Central Asia Related Regions. Ecological and Economic Problems of Nature use] 13: 118-120. (in Russian)

Krylov A.V. 2014. Zooplankton of the Durgun and Taishir reservoirs (Western Mongolia) at the end of the filling period. Aridnyye Ekosistemy [Arid Ecosystems] 20: 48-55 (in Russian)

Kudersky L.A. 1992. Ecological basis of the formation and use of fish resources of reservoirs. Dr. Sc. Dissertation, State Scientific Research Institute of Fisheries, Moscow, Russia. (in Russian)

Luferova L.A. 1964. The formation of zooplankton in the Gorky reservoir. Cand. Sc. Dissertation, Moscow State University, Moscow, Russia. (in Russian)
Makrushin A.V. 1974. Biologicheskiy analiz kachestva vod. Leningrad: USSR Academy of Sciences. (in Russian)

Opredelitel' presnovodnykh bespozvonochnykh Rossii i sopredel'nykh territoriy. Rakoobraznyye.1995. In: Tsalolikhin S.Ya. (Ed.). St. Petersburg: Nauka. (in Russian)

Popkov V.K., Golubykh O.S. 2005. Changes in the ecological state of Lake Chagytai and its fish population. In: Proceedings of the 7th International Conference "Natural conditions, history and culture of Western Mongolia and adjacent regions", pp. 244-247. (in Russian)

Rivier I.K., Lazareva V.I., Gusakov V.A. et al. 2001. Mezofauna verkhnevolzhskikh vodokhranilishch (1953 2001). In: Kopylov A.I. (Ed.), Ekologicheskiye problemy Verkhney Volgi. Yaroslavl', pp. 409-412. (in Russian)

Rukovodstvo po gidrobiologicheskomu monitoringu presnovodnykh ekosistem. 1992. In: Abakumov V.A. (Ed.). St. Petersburg: Gidrometeoizdat. (in Russian)

Sharonov I.V. 1966. Formirovaniye ikhtiofauny vodokhranilishch. In: Ekologiya vodnykh organizmov. Moscow, pp. 103-110. (in Russian)

Sladecek V. 1983. Rotifers as indicators of water quality. Hydrobiologia 100: 169-201.

Vorobyova S.S., Zemskaya T.I., Skryabin A.G. et al. 1981. Plankton Bratskogo vodokhranilishcha. Novosibirsk: Nauka. (in Russian)

Water management passport of a seasonal regulation reservoir on the Turan River of the Piy-Khem District of the Tuva Autonomous Soviet Socialist Republic. 1983. Chita: Chita Branch of Rosgiprovodkhoz. (in Russian)

Water management passport of a seasonal regulation reservoir on the Eerbek River of the Erbek farm in the Piy-Khem District of the Tuva Autonomous Soviet Socialist Republic. 1985. Chita: Chita Branch of Rosgiprovodkhoz. (in Russian) 